\title{
The addition of the salmon oil in the freezing of equine semen
}

\author{
A adição do óleo de salmão no congelamento do sêmen equino
}

\author{
AGOSTINHO, Raphael Farruk do Amaral ${ }^{1 *}$; ANDRADE, Vitor Ayub Assaf ${ }^{1}$; \\ CAIADO, Renato Pinheiro da Silva ${ }^{1}$; BARRETO, Marcus Antônio Pessanha ${ }^{1}$; \\ CAIADO, José Renato Costa ${ }^{1}$; SHIMODA, Eduardo ${ }^{2}$; SILVA, José Frederico \\ Straggiotti ${ }^{1}$
}

\footnotetext{
${ }^{1}$ Universidade Estadual do Norte Fluminense, Escola de Medicina Veterinária, Departamento de Reprodução Animal, Campos dos Goytacazes, Rio de Janeiro, Brasil.

${ }^{2}$ Universidade Candido do Mendes, Departamento de Estatística aplicada, Campos dos Goyacazes, Rio de Janeiro, Brasil.

*Endereço para correspondência: raphaelfarruk@hotmail.com
}

\section{SUMARY}

The aim of the present study was to verify the effect of salmon oil addition on cryopreservation of equine semen. The experiment consisted of two treatments. Treatment 1 (T1) (control diluent), BotuCrio ${ }^{\circledR}$ was used without addition of salmon oil and treatment 2 (T2) (experimental diluent) BotuCrio ${ }^{\circledR}$ plus (with) $2 \%$ salmon oil. Three ejaculates of four stallions were used, totalizing 12 collections $(n=12)$. Overall motility and progressive motility were evaluated by the Hamilton Thorn Research (HTR) Ceros 10.8 program, as well as the plasma membrane functionality through the hyposmotic test. Both treatments did not present statistical differences in relation to motility (T1 $25,2 \pm 1,7$ a, T2 $29,7 \pm 1,9$ a) and progressive motility (T1 $11,0 \pm 1,1$ a, T2 $14,1 \pm 1,3$ a). With respect to the hyposmotic test, the treatment 2 plus $2 \%$ of Salmon oil, presented better protection of sperm membrane functionality in relation to the control treatment (T2 77,3 $\pm 1,0$ a, T1 68,0 $\pm 1,0$ b). It can be concluded that salmon oil, although not altering the total and progressive motility, confers a better efficiency of sperm membrane functionality after thawing in equine semen.

Keywords: cryopreservation, equine spermatozoa, polyunsaturated fatty acids

\section{RESUMO}

O objetivo com este trabalho foi verificar o efeito da adição do óleo de salmão no congelamento do sêmen equino. $\mathrm{O}$ experimento constituiu de dois tratamentos. O tratamento 1 (T1) (diluente controle), utilizou-se o BotuCrio ${ }^{\circledR}$ sem a adição de óleo de salmão e o tratamento 2 (T2) (diluente experimental) BotuCrio ${ }^{\circledR}$ adicionado de $2 \%$ de óleo de salmão. Foram utilizados três ejaculados de quatro garanhões, totalizando doze coletas $(\mathrm{n}=12)$. Avaliou-se a motilidade total e motilidade progressiva pelo programa Ceros 10.8 da Hamilton Thorn Research (HTR), além da funcionalidade de membrana plasmática através do teste hiposmótico. Ambos os tratamentos não apresentaram diferenças estatísticas em relação a motilidade total (T1 $25,2 \pm 1,7$ a, T2 $29,7 \pm 1,9$ a) e motilidade

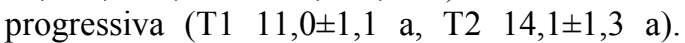
Com relação ao teste hiposmótico, o tratamento 2 acrescido de $2 \%$ de óleo de Salmão, apresentou melhor proteção da funcionalidade de membrana espermática em relação ao tratamento controle (T2 77,3 $\pm 1,0$ a, T1 68,0 $\pm 1,0$ b). Pode-se concluir que o óleo de salmão, apesar de não alterar a motilidade total e progressiva, confere uma melhor eficiencia da funcionalidade de membrana espermática pós descongelamento em sêmen de equinos.

Palavras-chave: criopreservação, espermatozóide equino, ácidos graxos poliinsaturados 


\section{INTRODUCTION}

The changes in equine spermatozoa during the cryopreservation process have led to an increasing number of studies in this area, in order to minimize sperm damage and improve the low pregnancy outcomes, which are still not satisfactory, which limits their commercial use. However, even with the best cryopreservation protocols, fertility rates obtained using frozen semen from some stallions remain lower than those obtained with fresh and refrigerated semen, varying greatly between stallions (GOMES et al., 2009, LOVE, 2012) .

An alternative to minimize sperm damage caused by freezing is the search for more effective cryoprotectants and additives, (HARTWIG et al., 2012). Holt (2000) stated that there are differences in lipid composition of the sperm membrane between individuals of the same species, in the same and different races. In many species of mammals, more than $60 \%$ of spermatic membrane fatty acids are long chain polyunsaturated fatty acids (PUFA) of the omega three $(\omega 3)$ series (NISSEN \& KREYSEL, 1983). This specific lipid composition confers greater fluidity to the plasma membrane due to the presence of some double bonds (OLIVEIRA et al., 2006). According to studies, the lipids that make up the plasma membrane of spermatozoa are particularly unsaturated, docosahexaenoic acid (DHA, $30 \%$ ) and docosapentanoic acid (DPA, $25 \%$ ) (OLIVEIRA et al., 2006). It is also known that the freezing of spermatozoa affects the lipid composition of the spermatozoa (STEPONKUS et al., 1983). The increase in the degree of unsaturation and, therefore, the fluidity of the membrane, could increase the spermatozoa resistance to the damages caused by the cooling / thawing process (PAULENZ et al., 1999). Salmon oil has $13 \%$ DHA in its composition, so salmon oil may be an option to increase the content of fatty acids (DHA and DPA) and, consequently, could increase the spermatozoa resistance to the damages caused by the process of cooling / thawing, probably due to the adsorption of these elements in the plasma membrane of these cells, repairing or maintaining their integrity. The objective of this work was to verify the effect of the addition of salmon oil on cryopreservation of equine semen.

\section{MATERIAL AND METHODS}

This animal experimentation was performed with the approval of the Comissão de Ética de Uso de Animais (CEUA - UENF) in accordance with the Sociedade Brasileira de Ciência de Animais de Laboratório / Colégio Brasileiro de Experimentação animal (SBCAL / COBEA).

Four Mangalarga Marchador stallions were collected, breed from 3 to 10 years old at Galopante Stud (Campos dos Goytacazes/RJ) and Gramont Stud (Campos dos Goytacazes/RJ), during the breeding season 2013 / 2014. The stallions were maintained in a individual boxes. Water and mineral salt were available ad libitum. All animals presented good body condition.

The semen samples were obtained for five consecutive days before the experimental period, to stabilize the extra-gonadal sperm reserves. Three ejaculates were used per stallion, totalizing twelve collections $(n=12)$. During the experimental period the stallions were submitted to a semen collection routine of three times in a 
week in order to perform the semen freezing.

A Botucatu model artificial vagina was used with a Colorado model filter, using a mare in estrous for the collection. At collection, the gel portion was filtred and the semen was diluted in a proportion of $1: 1 \quad$ (Botu Sêmen ${ }^{\circledR}$ Botupharma, Botucatu/SP-Brazil), cooled in a thermal box to an average temperature of $15^{\circ} \mathrm{C}$, and transported for 20 minutes to the State University of Northern Fluminense (UENF) for the initial evaluation of the macro (color, appearance and odor) and microscopic (sperm concentration, sperm motility) characteristics.

The diluent used for freezing was Botucryo ${ }^{\circledR}$ (Botupharma, Botucatu/SPBrazil). The experimental product was the salmon oil (Vila Ervas ${ }^{\circledR}$ ), whose composition is: $360 \mathrm{mg}$ of EPA (eicosopentaenoic acid) and $240 \mathrm{mg}$ of DHA (docosahexaenoic acid) in 1000 mg. The experimental diluent consisted of the addition of $2 \%$ salmon oil, according to Andrade (2013), in the commercial diluent Botu-cryo ${ }^{\circledR}$. Immediately after the initial analyzes, the semen was placed in a $15 \mathrm{~mL}$ Falcon Tubes and centrifuged at $600 \mathrm{G}$ for 10 minutes, for seminal plasma removal and resuspended in freezing diluent $\left(\mathrm{T} 1=\right.$ BotuCrio ${ }^{\circledR}$ and $\mathrm{T} 2=$ BotuCrio ${ }^{\circledR}$ plus $2 \%$ salmon oil) at a concentration of 50 million spermatozoa per pallets. The samples were packed in conventional $0.5 \mathrm{~mL}$ pallet and sealed with polyvinyl ponder (Minitub- Porto Alegre/ Brazil). The sêmen was cooled at $5{ }^{\circ} \mathrm{C}$ for 20 minutes. After this time, the samples were placed at $4 \mathrm{~cm}$ from the liquid nitrogen surface for 20 minutes and plunged into liquid nitrogen. For thawing the pallets, were mantained in a water at $37{ }^{\circ} \mathrm{C}$ for 30 seconds (PAPA, 2007).
Sperm motility was assessed by the Hamilton Thorn Research computerized analysis system model Ceros 10.8 using a specific program for equine semen analysis. Each sample was placed on a preheated slide at $37{ }^{\circ} \mathrm{C}$ and covered with a cover slide and analyzed under a 100x magnification optical microscope coupled to the computer. For the sperm motility, the parameters of total (MOT, $\%$ ) and progressive (PGM, \%) were analyzed. The functionality of the spermatic membrane was evaluated through the hyposmotic test. In a microcentrifuge tube was placed $950 \mu \mathrm{L}$ of distilled water and supplemented with $50 \mu \mathrm{L}$ of semen. The samples were incubated for 5 minutes at $37^{\circ} \mathrm{C}$ water (DELL'A QUA et al., 2002). After, the semen sample it was examined under a phase contrast microscope with a magnification of $400 x .200$ sperm cells were counted, cells with functional membrane were considered those that had the tail bent or rolled and nonfunctional to those that remained with the tailed tail. The experimental design used in this experiment was a randomized block with three replicates (ejaculate), with two treatments: Trat 1 $=$ Botu-Crio ${ }^{\circledR}$ commercial diluent (control) and Trat $2=$ Botu-Crio ${ }^{\circledR}$ commercial diluent plus $2 \%$ oil Of Salmao (Vila ervas ${ }^{\circledR}$ ) all stored in 0.5 $\mathrm{mL}$ pallet and sealed with polyvinyl alcohol.

In this experiment, the mean and standard errors of total motility (MT), progressive motility (MP) and sperm plasma membrane functionality by treatment (1 and 2) and by collection (1st, 2nd and 3rd) were obtained as shown in Table 1 . The existence of effect of the treatments was tested by Student's t-test, and the significance ( $P$ value) was presented. Statistical analyzes were performed using the System for Statistical and Genetic 
Analysis (SAEG, version 9.1), with a $5 \%$ level of significance.

\section{RESULTS AND DISCUSSION}

A significant difference $(\mathrm{P}<0.05)$ was observed in only one of the collections performed to evaluate total motility. Observing that the experimental group
$(33.9 \pm 3.5$ a) had an increase of this paramenter compared to the control group $(24.0 \pm 2.9 \mathrm{~b})$.

There was no difference $(p>0.05)$ in the parameter of progressive motility (PGM) by collection (1st, 2nd and 3rd) and by treatment $\left(\mathrm{T} 1=\right.$ BotuCrio ${ }^{\circledR}$ without addition of salmon oil and $\mathrm{T} 2=$ Botu-cryo ${ }^{\circledR}$ diluent $+2 \%$ oil Of salmon).

Table 1. Means and standard errors of motility (MOT), progressive motility (PGM) and membrane functionality (nonfunctional and functional) by collection (1st, 2nd and $3 \mathrm{rd})$ and by treatment $\left(\mathrm{T} 1=\right.$ BotuCrio ${ }^{\circledR}$ without addition of salmon oil And T2 $=$ Botu-crio ${ }^{\circ}$ diluent $+2 \%$ salmon oil) of four Mangalarga Marchador stallions

\begin{tabular}{lcccc}
\hline Variable & Collection & Treatment 1 & Treatment 2 & P \\
\hline \multirow{4}{*}{ Motility } & 1 & $23,7 \pm 2,9^{\mathrm{a}}$ & $26,9 \pm 2,8^{\mathrm{a}}$ & 0,4341 \\
& 2 & $24,0 \pm 2,9^{\mathrm{b}}$ & $33,9 \pm 3,5^{\mathrm{a}}$ & 0,0343 \\
& 3 & $27,9 \pm 3,2^{\mathrm{a}}$ & $28,3 \pm 3,7^{\mathrm{a}}$ & 0,9432 \\
& Means & $25,2 \pm 1,7^{\mathrm{a}}$ & $29,7 \pm 1,9^{\mathrm{a}}$ & 0,0835 \\
Progressive Motility & 1 & $11,6 \pm 1,9^{\mathrm{a}}$ & $13,7 \pm 2,2^{\mathrm{a}}$ & 0,4933 \\
& 2 & $10,3 \pm 1,7^{\mathrm{a}}$ & $16,3 \pm 2,5^{\mathrm{a}}$ & 0,0583 \\
& 3 & $11,2 \pm 2,0^{\mathrm{a}}$ & $12,3 \pm 2,2^{\mathrm{a}}$ & 0,7246 \\
Nonfunctional membrane & Means & $11,0 \pm 1,1^{\mathrm{a}}$ & $14,1 \pm 1,3^{\mathrm{a}}$ & 0,0780 \\
& 1 & $32,3 \pm 1,5^{\mathrm{a}}$ & $20,4 \pm 1,5^{\mathrm{b}}$ & $<0,0001$ \\
& 2 & $33,9 \pm 1,9^{\mathrm{a}}$ & $24,9 \pm 1,6^{\mathrm{b}}$ & 0,0008 \\
& 3 & $29,9 \pm 1,9^{\mathrm{a}}$ & $23,0 \pm 1,9^{\mathrm{b}}$ & 0,0151 \\
Functional membrane & Means & $32,0 \pm 1,0^{\mathrm{a}}$ & $22,8 \pm 1,0^{\mathrm{b}}$ & 0,0002 \\
& 1 & $67,8 \pm 1,5^{\mathrm{b}}$ & $79,7 \pm 1,5^{\mathrm{a}}$ & $<0,0001$ \\
& 2 & $66,1 \pm 1,9^{\mathrm{b}}$ & $75,1 \pm 1,6^{\mathrm{a}}$ & 0,0008 \\
& 3 & $70,2 \pm 1,9^{\mathrm{b}}$ & $77,0 \pm 1,9^{\mathrm{a}}$ & 0,0151 \\
& Means & $68,0 \pm 1,0^{\mathrm{b}}$ & $77,3 \pm 1,0^{\mathrm{a}}$ & 0,002 \\
\hline
\end{tabular}

Equal letters in the same column don't show statistical difference between the means $(p>0.05)$ by the Student $t$ test.

These results corroborate with Grady et al. (2009), that when supplementing fish oil as a source of omega three $(\omega 3)$ in the diet of stallions, did not observe improvement in the parameters of motility and progressive motility in equine fresh, refrigerated and cryopreserved semen. Like Brinsko et al. (2005), when adding docosahexaenoic acid (DHA) in the diet of stallions did not observe improvement in the quality of the equine semen to fresh, refrigerated and cryopreserved. However, when adding fish oil in Botu-crio ${ }^{\circledR}$ freezing diluent in equines, Andrade (2013) obtained an 
improvement $(\mathrm{P}<0.05)$ in the parameters motility and progressive motility in the collection of a single stallion. In the present study, because four stallions were used, the non significant statistical difference among the treatments was explained by the decrease in individual stallion variation due to the larger sample population obtained in this experiment.

Regarding membrane functionality, there was a significant difference ( $P$ $<0.05$ ) by collection and treatment, where the experimental group (77.3 \pm 1.0 a) was more efficient in relation to the control group $(68.0 \pm 1.0 \mathrm{~b})$, as described in Table 1. It is observed a higher percentage of functional membrane sperm and a lower percentage of damaged cells after thawing in the diluent where $2 \%$ of salmon oil was added as compared to the control group. This result corroborates the results found by Andrade (2013) in horses and Chanapiwat et al. (2009), who studied the effect of DHA semen quality of swine semen, where they found a better result obtained by the combination of egg yolk enriched in DHA + L-cysteine. This study demonstrates the importance of the role of this association in the protection of the structure and function of the plasma membrane, increasing PUFA levels in the membrane, improving its fluidity and flexibility due to the presence of some double bonds. Also the results found in this paper agree in part with the results of Kaeoket et al. (2010) evaluated the effect of supplementation of DHA (fish oil) on the freezing diluent on semen quality in different pig breeds, resulting in higher plasma membrane integrity after thawing. They argued that spermatozoa may have adsorbed and used DHA to maintain and repair their plasma membrane and, consequently, damage of the plasma membrane and organelles of the spermatozoa, such as mitochondria, decreased. The addition of salmon oil may indicate the great importance of these lipids in the preservation of sperm attributes, once observed that salmon oil effectively protects the membrane functionality of equine sperm cells. It is concluded that the addition of $2 \%$ of salmon oil in the cryopreservation diluent of equine semen, although not altering the total and progressive motility, confers a better efficiency of the sperm membrane functionality after thawing.

\section{ACKNOWLEDGMENTS}

To the veterinary friends and breeders José Renato Costa Caiado, Renato Pinheiro da Silva Caiado and Marcus Antônio Pessanha Barreto for having given the animals for this study, to Professor Eduardo Shimoda for the accomplishment of the statistic and the Professor and friend José Frederico Straggiotti Silva for the technical support.

\section{REFERENCES}

ANDRADE, V.A.A. Utilização de óleo de peixe na criopreservação de sêmen equino. 2013. 47f. Monografia (Conclusão de curso em Medicina Veterinária) - Universidade Estadual do Norte Fluminense, Campos dos Goytacazes, Rio de Janeiro.

AVANZI, B.R.; RAMOS, R.S.; DELL'AQUA JUNIOR, J.A.; PAPA, F.O. Avaliação da cinética espermática, integridade de membrana plasmática e resistência ao estresse oxidativo no sêmen equino congelado com diferentes concentrações espermáticas. Veterinaria e Zootecnia, v.18, n.2, 2011. 
BRINSKO, S.P.; VARNER, D.D.; LOVE, C.C.; BLANCHARD, T.L.; MARK, B.C.; WILSON, E. Effect of feeding a DHA-enriched nutriceutical on the quality of fresh, cooled and frozen stallion semen. Theriogenology, v.63, p.1519-1527, 2005.

CHANAPIWAT, P.; KAEOKET, K.; TUMMARUK, P. Effects of DHAenrichedhen egg yolk and L-cysteine supplementation on quality of cryopreserved boar semen. Asian

Journal of Andrology, v.11, p.600-608, 2009.

GRADY, S.T.; SCOTT, B.D.; BRINSKO, D.W.; FORREST, D.W.; SAWYER, J.E.; CAVINDER, C.A. Dietary supplementation of 2 soucers of omega 3 fatty acids and subsequent effects on fresh, cooled and frozen seminal characteristics of stallion. Journal of Equine Veterinary Science, v.29, n.5, p.333-33, 2009.

GOMES, G.M.; GOMES L.P.M. Problemas e soluções com o uso de sêmen congelado e refrigerado de garanhões da raça Mangalarga Marchador. Revista Brasileira de Reprodução Animal, v.6, p.210-215, 2009. Suppl.

HARTWIG, F.P.; PAPA, F.O.; DELL'AQUA JUNIOR, J. Utilização do colesterol na criopreservação de espermatozóides na espécie equina: Uma revisão. Veterinária e Zootecnia, v.19, n.2, p.157-168, 2012.

HOLT, W.V. Basic aspect of frozen storage of semen. Animal Reproduction Science, v.62, p.3-22, 2000.

KAEOKET, K.; SANG-URAI, P.; CHANAPIWAT, P.; TECHAKUMPHU, $M$. Effect of docosahexaenoic acid on quality of cryopreserved boar semen in different breeds. Reproduction in

Domestic Animals, v.45, n.3, p.458-63, 2010.

LOVE, C.C. Measurement of Concentration and Viability in Stalion Sperm. Journal of Equine Veterinary Science, v.32, n.8, p.464-466, 2012.

NISSEN, H.P.; KREYSEL, H.W. Polyunsaturated fatty acids in relation to sperm motility. Andrology, v.15, p.264269, 1983.

OLIVEIRA, S.L.; FIALHO, E.T.; MURGAS, L.D.S.; FREITAS, R.T.F.; ZANGERONIMO, M. G. Efeito da Inclusão de diferentes tipos de oleo na dieta de varrões sobre a qualidade do semen in natura. Ciência e Agrotecnologia, v.30, n.6, p.1205-1210, 2006.

PAPA, F.O.; ALVARENGA, M.A.; DELL'AQUA JUNIOR, A. Manual de andrologia e manipulação de sêmen eqüino. São Paulo: Botupharma, 2007. 60p.

PAULENZ, H.; TAUGBOL, O.; KOMMISRUD, E. GREVLE, I.S. Effect of dietary supplementation with cod liver oil on cold shock and freezability of boar sêmen. Reproduction in Domestic Animals, v.34, p.431-435, 1999.

Data de recebimento: 06/07/2017

Data de aprovação: 27/11/2017 